\begin{tabular}{c} 
Volume and Issues Obtainable at Center for Sustainability Research and Consultancy \\
Journal of Accounting and Finance in Emerging Economies \\
ISSN: 2519-0318 ISSN (E) 2518-8488 \\
Volume 4: Issue 1 June 2018 \\
CSRᄃ \\
Journal homepage: www.publishing.globalcsrc.org/jafee \\
\hline
\end{tabular}

\title{
Stock Market Reaction to Election Cycles: The Nigerian Experience
}

\author{
${ }^{1}$ Sharlywest Uwabor EBOIGBE, ${ }^{2}$ Kennedy Prince MODUGU \\ ${ }^{1}$ Department of Banking \& Finance, Faculty of Management Sciences, University of Benin, Nigeria. \\ princekenny2010@gmail.com \\ ${ }^{2}$ Department of Accounting, College of Financial \& Administrative Sciences, AMA International University, \\ Bahrain.
}

\begin{tabular}{l}
\hline ARTICLE DETAILS \\
\hline History \\
Revised format: May 2018 \\
Available online: June 2018 \\
\\
\hline Keywords \\
Stock Market, Election Cycle, \\
Depoliticization, Power \\
Swings, Directors
\end{tabular}

JEL Classification:

G14,D72

\begin{abstract}
This study seeks to unravel the relationship between national electoral events and industry's stock market returns using the various presidential elections in Nigeria. The study adopts the traditional Market Model (MM) and testing with the Cumulative Abnormal Return (CAR) approach on the daily market data from the Nigerian Stock Exchange. Evidences abound that banking and Petroleum sector decreases before and increases after all elections. With the same trend for other sectors such as Conglomerates stock prices which oscillated in the same direction for the1999 and 2003; Brewery took their turn 1999 and 2011 while building sector experienced this event effect in 1999, thereby revealing industry connectivity with political activities. This manifests as their stock returns tend to reduce generally before and increase after election periods. We therefore recommend the depoliticization of public policies through strict adherence to corporate governance codes and strengthening of public institutions. This will put a check on the political manoeuvrings of the economy by boosting investors' confidence on the market regardless of electoral activities and power swings. More importantly, for those stocks that experiences increase in value after election it is a better time to sell those portfolios and buy these stocks that experience loss in value at a post-election window.
\end{abstract}

(C) 2018 The authors, under a Creative Commons AttributionNonCommercial 4.0

Corresponding author's email address: princekenny2010@gmail.com

Recommended citation: EBOIGBE, S. U., MODUGU, K. P.. (2018). Stock Market Reaction to Election Cycles: The Nigerian Experience. Journal of Accounting and Finance in Emerging Economies, 4(1) 63-76

DOI: $10.26710 /$ jafee.v4i1.345

\section{Introduction}

Political connection is where one or more of a company's directors have the same educational, social, cultural and religious affinity with the key actors in government from whom they can draw economic advantage. This often manifest with political actors having units of corporate ownership in the firms. It can also be seen with different employment arrangements in politically disadvantage areas with government in power. Political connectivity of firms confers competitive advantage on firms in the areas of ease of access to financing, funding and tax holidays for politically connected firms. It also facilitates contracts between political actors and board of director for mutual advantage.

Economic manifestation of political exposures of firms to government spending affect the capital market volume of trade as well as market returns (Agrawal \& Knoeber, 2001; Khwaja\&Mian, 2005; Goldman, 
Rocholl \& So, 2008). Politically connected firms tends to adjust their employment and dismissal policies and have higher rates of job and branch network creation before election. They sometimes superfluously maintain low rates of plant and product line deletion. Low profits, higher labour costs and robust labour relation in election years just to help incumbent government in their re-election bid to portray a healthy economy to the ill-informed electorates. Here new jobs and plants are established despite unproductive product lines within the election window (Kramarz \& Thesmar, 2007; Bertrand, Kramarz, Schoar \& Thesmar, 2008; Cohen, Frazzini \& Malloy, 2008; Fracassi, 2009; Do, Lee, Nguyen \& Nguyen, 2012; Nguyen, 2012). Such political turnover substantially diffuse into stock market performance of politically linked firms. These aforementioned are validated in literaturewith positive relationship (Fisman, 2001; Kroszner and Strahan, 2001; Bunkanwanicha and Wiwattanakantang, 2009; Aggarwal, Meschke and Wang, 2008; Boubakri, Cosset and Saffar, 2008; Guner, Malmendier and Tate, 2008; Goodell and Vahamaa, 2013).

The study examines the link between politically connected firms/industry' and the aggregate demand, supply and market equilibrium of their stocks returns within an electoral cycle (before and after political events-elections). This is motivated by Bertrand, Kramarz, Schoar and Thesmar, (2007) rebuttal of absence of a causal link between political connectedness of firms and firms' performance. The other school of thought avows neutrality of political inclination of owners to firms' turnover Fisman, Fisman, Galef and Khurana, (2006). Knight (2007) reveals that policies in a party's platform transmit positive incremental values into equity prices through returns from industries favoured by a particular party. Roberts (1990), Santa-Clara \&Valkanov (2003) and Sy \& Al Zaman (2011) aver further that politically determined events manifest at both macro and microeconomic levels. This they demonstrate with the death of very senior and influential Washington senator resulting in lower abnormal returns for firms where he has a stake implying that specific client-firms relationship is a building block for firms' performances.

In the light of the aforesaid, this research seeks to determine the relationship between national electoral events and some specific industry stock market returns exist.Variability in economic (financial markets, monetary and fiscal) activities originating from external interference or politically aware actors seeking to be re-elected is termed opportunistic business cycle theory. This concept in underpinned by the assumption that there exist a short-term trade-off between level of manpower and resources utilization as well as employment and inflation in the aggregate economy within an administration cycle.

As political officeholders are rational actors who rank their political objectives in order of priority, it is therefore incumbent on financial economist, accountants, researchers and investors to keep an eye on these players and their intentions. Since individuals and corporate personnel have trade-offs like consumption-investment tangles as well as labour-leisure trade-off, the study of aggregates economy and the interdependent variables using real business cycle model foresees that during temporary shock indicators like productivity, consumption, investment and employment varies from their respective longterm and trend projection. Therefore, business cycles are a product of accumulation or de-accumulation of wealth, which is determine by the prevailing national politico-economic culture (Blomberg \& Hess, 2003). These models integrate many factors upon which economic variations hinge but fail to take cognisance of office-bearers influence in the cycles powered by their quest for re-election. As individuals have preferences, so also do incumbent and opposition governments. Such preference may not be consistent with the need of economy at that point. Therefore, politicians and their parties cannot be trusted with proper and public-oriented macroeconomic policies driven by industry, economic and company's fundamentals. This is because of politicians' determination to adjust institutional capacity of existing economic policies and structures with a view to realizing their short term aim of winning elections. Therefore this study seeks to unravel the relationship between national electoral events and industries stock market earnings and returns. 


\section{Review of Related Literature}

Greenwood and Thesmar (2011) study the relation between ownership structure, financial assets market prices and non-fundamental risk. They see an asset fragility as caused by its vulnerability to shifts in demand driven by non-fundamentals. They affirm that as owners are faced with volatility and liquidity shocks caused by buy or sell, the units of asset ownership experience wide returns variability. This is further explained by the reappearance of high electioneering cost which might lead owners to sell for funding purpose. Consistent with Greenwood and Thesmar (2011) and many other expectations, fragility denotes price volatility not dependent on the fundamental. The dislocating impact of arbitrageurs on stock prices due to arbitrage in the outdated asset pricing theory lends credence to impact on sales volume and price movement.

We argue that ownership composition of assets ought not to influence future risk and returns predictability, but where current holders' buys or sells for reasons unrelated to fundamentals, there will be an impact on the price. Fragility of the market is a function of ownership concentration, volatilities and holders' expected liquidity preferences. The connectivity between ownership structure and risk therefore buttresses the impact of institutional ownership role on stock price volatility (Johnson \& Mitton, 2003; Faccio, 2006; Faccio, Masulis\& McConnell, 2006; Jachandran, 2006; Faccio\& Parsley, 2007; Goldman, Rocholl\& So, 2007; Claessens, Feijen\&Laeven, 2008).

During partisanship political business cycle, companies' exposure to public spending envisages crosssectional effect as such industries stock returns outperform firms in similar and dissimilar industries with low exposure to public expenditure (Santa-Clara \&Valkanov, 2003). This activities create abnormal returns which is usually in the second and third year of administrations term and wanes in electoral years. They asserts that this disappearance shows that political linkage pull down profits as employment wage bill surges in highly challenged areas resulting an increase in social welfare cost. Their conclusion means that political exposures doest not only create some benefits without concomitant costs.

Premise on these divergences, we hypothesized that:

H1: There is significant negative relationship between the performance of companies with politicallyexposed directorship/ownership and election cycle

\section{Methodology}

\subsection{Research Design, Sample and Data.}

The longitudinal research design was adopted due to its usefulness in determining the trend of a unit or a group of items over a period of time. Trading stocksprices in Nigerian Stock Exchange were grouped on the basis of industry for the period of the various elections (1999, 2003, $2007 \& 2011)$ were used. Eventstudy-approach where elections in the country forms the basic event was also adopted.The market model (MM) was used for this study as a result of its good characteristics of not supposing the random walk philosophy of stock returns in relation with market portfolio returns. The model has robust belief of joint normality of the returns (Campbell et al 1997\& Mackinlay, 1997). For the estimation of the factors of normal performance, the following comes to the fore.

Where:

$$
\boldsymbol{R}_{i t}=\alpha_{i}+\boldsymbol{\beta}_{i m} \boldsymbol{R}_{m t}+\varepsilon_{i t}
$$

Rit $=$ realized return for $i$ stock in time period $t$.

$\mathrm{R}_{\mathrm{m}}=$ realized return for index in time period t. Here the banking index is used

$\alpha_{\mathrm{i}, \text { and }} \beta_{\mathrm{i}}=$ regression coefficients.

In the mathematical computation, the normal return is

$$
\mathrm{R}_{\mathrm{it}}=\alpha_{\mathrm{i}}+\beta_{\mathrm{i}} \mathrm{R}_{\mathrm{mt}}
$$

The daily rates of return for each company stock price index are calculated as follows:

$$
\boldsymbol{R}_{t}=\ln \left(\frac{S P_{t}}{S P_{t-1}}\right) * 100
$$

Where: 


$$
\begin{aligned}
& \mathrm{R}_{\mathrm{t}}=\text { return on share price } \\
& \mathrm{SP}_{\mathrm{t}}=\text { contemporary share price } \\
& \mathrm{SP}_{\mathrm{t}-1}=\text { previous period share price } \\
& \ln =\text { natural logarithm }
\end{aligned}
$$

The abnormal return is the difference between actual return on the event window and estimated or expected return. In this study, we adopt the method of estimating the abnormal return which is frequently referred to as the residual analysis. Here the residual term in equation $(1 \& 2)$ is assumed to indicate the abnormal return computed (see Eriki \& Eboigbe, 2012) as:

$\mathrm{AR}_{\mathrm{it}}=R_{i t}-\left(\alpha_{i}+\beta_{i m} R_{m t}\right)(4)$

A testing framework of the study needs to be defined for any abnormal returns calculated, including the definition of the null hypothesis and techniques for aggregating the results over time and across individual firms. This studies as those before it, adopts the cumulative abnormal return (CAR) approach, defined as the sum of the abnormal returns for each day in the event window: $C A R i=\Sigma A R i t$

(5)

Under the null hypothesis, the given event has no impact on the mean or variance of returns, hence the expectation of abnormal returns is zero. Inferences about the CAR will be drawn using a test statistic: $\mathrm{t}=$

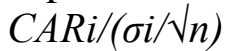

$\sigma i$ is The standard error of the distribution and $n$ is the number of days in the event window.

The results from the event study will be used to examine the impact of the appearance of unanticipated information from the electoral events on the unstable nature of the market earnings. To examine this, the difference in stock returns on daily basis for all firms are calculated for the pre- and post-election days as well as for the days without elections. This alterations are calculated using this formula: $\operatorname{Var}=$

$\frac{1}{N_{j}-1} \sum_{t=1}^{N_{j}}\left(R_{i t}-\bar{R}_{i j}\right)^{2}$

Where $\mathrm{N}_{\mathrm{j}}=$ Number of days in each category (before and after as well as the days without the event), $\mathrm{R}_{\mathrm{it}}=$ the return daily for firm $i$ on day $t, \bar{R}_{i j}$ represents the mean return for each grouping (before and after as well as the days without the event).

\section{Result Presentation and Discussion of Findings}

The result of the initial estimation is reported in table (i) below. From the table, estimates of alphas and betas are shown for the industries in each of the election periods. Only the coefficient of the banking and petroleum sector were significant throughout the entire periods. This shows that the event of essence transmits its impact into the market price as it tends to significantly stimulate the prices of stocks in these sector. The coefficients of insurance and chemical sectors were significant for some of the years, suggesting that these sectors were also active for some years in the market during elections.

\section{Table (1): Estimates of the $\alpha$ 's and $\beta$ 's for each of the Firms}

\begin{tabular}{lcccccccc}
\hline \multirow{2}{*}{ Company } & \multicolumn{2}{c}{$\mathbf{2 0 1 1}$} & \multicolumn{2}{c}{$\mathbf{2 0 0 7}$} & \multicolumn{2}{c}{$\mathbf{2 0 0 3}$} & \multicolumn{2}{c}{1999} \\
\cline { 2 - 9 } & $\boldsymbol{\alpha}$ & $\boldsymbol{\beta}$ & $\mathbf{A}$ & $\boldsymbol{\beta}$ & $\boldsymbol{\alpha}$ & $\boldsymbol{\beta}$ & $\mathbf{A}$ & $\mathbf{B}$ \\
\hline Agriculture & 0.01 & 0.11 & -0.05 & 0.03 & -0.06 & 0.04 & -0.08 & 0.05 \\
Banking & -0.28 & $0.85^{* *}$ & $-0.36^{*}$ & $0.25^{* *}$ & -0.48 & $0.33^{*}$ & -0.64 & $0.44^{* *}$ \\
Breweries & 0.24 & 0.09 & 0.20 & -0.14 & 0.26 & -0.18 & 0.35 & -0.24 \\
$\begin{array}{l}\text { Building } \\
\text { materials }\end{array}$ & 0.16 & 0.11 & -1.54 & 1.08 & -2.02 & $1.42^{*}$ & -2.71 & 1.90
\end{tabular}




\begin{tabular}{|c|c|c|c|c|c|c|c|c|}
\hline $\begin{array}{l}\text { Chemical and } \\
\text { paints }\end{array}$ & 0.01 & 0.17 & 1.05 & 0.74 & 1.38 & 0.97 & 1.85 & 1.30 \\
\hline Conglomerates & 0.00 & 0.08 & 0.14 & -0.10 & 0.18 & $0 . \overline{13} *$ & 0.24 & $-0.17 *$ \\
\hline Construction & -0.05 & -0.04 & -0.63 & 0.44 & -0.83 & 0.58 & -1.11 & 0.78 \\
\hline Healthcare & -0.04 & -0.05 & -0.27 & 0.20 & -0.36 & 0.26 & -0.48 & 0.35 \\
\hline Insurance & -0.07 & 0.04 & -0.33 & 0.23 & -0.44 & 0.30 & -0.59 & 0.40 \\
\hline Petroleum & -0.08 & $-0.23^{*}$ & 0.02 & -0.02 & 0.03 & $0.02 *$ & 0.04 & $-0.03 *$ \\
\hline
\end{tabular}

Note: $*$ significance at 5 percent; $* *$ significance at 1 percent.

Source: Authors' computations, 2017

The abnormality of returns obtained from the estimated market models are presented in successive tables for each of the election periods under consideration. Using the results of the estimated normal returns model obtained in table (1) above, the abnormal returns on each of the stocks during the estimation periods are obtained. The outcome of abnormal return for each stock price for 10 days before and ten days after the presidential elections are presented in tables 2 to 5 below. From the trends for 1999 as shown in table (ii), the patterns of the return movements during the period are emphasized. For most of the stock returns, there were more negative outcomes for the period before the elections than for the period after the elections. This generally shows that for the period close to elections, stock returns tend to perform relatively poor.

Table (2): Abnormal Returns for the Firms, 1999 (10 days Pre-and post-elections)

\begin{tabular}{crrrrrrrrrrr}
\hline Day & agric & Bank & brew & Build & Chem & Congl & Constr & Health & Indust & insur & Petrol \\
\hline-10 & -0.90 & -0.71 & 1.83 & -0.05 & 1.04 & -0.86 & 0.06 & 1.28 & 0.57 & -1.08 & 2.20 \\
-9 & 0.83 & -0.17 & 0.47 & -1.20 & -0.06 & -0.25 & 0.05 & -1.44 & -1.20 & -1.09 & -0.51 \\
-8 & -0.77 & 0.28 & 1.61 & 1.45 & 0.01 & 1.21 & -1.71 & -0.93 & 1.26 & 0.36 & 0.99 \\
-7 & -0.29 & 0.00 & -0.08 & -1.16 & -0.42 & -0.27 & 0.02 & -0.63 & 0.18 & 1.20 & -0.45 \\
-6 & -0.29 & -0.64 & 1.23 & 1.38 & -0.05 & -0.19 & -0.40 & -0.07 & 0.75 & 1.04 & -0.05 \\
-5 & -1.04 & -0.06 & 1.74 & -2.77 & -1.62 & -0.70 & -3.32 & -0.68 & -1.28 & -0.67 & 0.19 \\
-4 & 0.29 & -0.35 & 1.16 & -1.02 & 0.79 & 0.62 & -0.13 & -1.14 & -1.71 & -1.02 & 1.22 \\
-3 & -0.28 & 1.00 & -4.92 & 3.07 & 1.80 & -1.08 & -3.75 & 0.57 & -0.54 & 1.34 & -0.68 \\
-2 & -0.28 & -0.52 & -2.38 & -0.08 & -1.97 & -2.13 & -3.22 & -0.77 & 0.04 & -0.91 & -1.20 \\
-1 & -0.21 & 0.11 & -1.48 & 2.15 & -0.40 & 1.40 & -0.06 & 0.73 & 0.96 & 1.19 & 1.26 \\
1 & 0.28 & -2.03 & 0.21 & -4.20 & -2.38 & 2.46 & 0.07 & 1.44 & -0.30 & 0.22 & -0.68 \\
2 & 0.28 & -0.19 & -2.46 & -0.34 & -0.01 & -0.18 & -0.36 & 1.25 & -0.64 & -0.36 & 1.65 \\
3 & 0.28 & 1.26 & 0.08 & 1.92 & -0.39 & 2.11 & -0.06 & -1.71 & -0.06 & 1.08 & -1.95 \\
4 & -0.28 & 0.48 & 2.92 & 0.47 & 0.07 & 0.23 & -0.07 & 0.68 & -1.10 & 1.36 & -0.06 \\
5 & -0.28 & 0.59 & -0.75 & 0.12 & 0.30 & -1.48 & 3.18 & 0.67 & 1.78 & 0.07 & 1.20 \\
6 & 0.27 & 0.53 & -1.45 & 2.54 & 0.16 & -1.56 & -0.08 & 0.04 & 0.24 & -0.54 & 1.88 \\
7 & 0.27 & 0.76 & 0.01 & -1.90 & 0.39 & -1.37 & 2.09 & 2.11 & -0.74 & 0.73 & -1.21 \\
8 & -2.20 & 0.56 & -0.11 & 0.81 & 0.69 & 1.10 & -0.24 & 2.08 & -0.33 & 0.40 & -0.13 \\
9 & -2.17 & 0.77 & 0.21 & 1.90 & 1.44 & 1.74 & 3.29 & -2.43 & 0.71 & 2.64 & 0.07 \\
10 & 0.27 & 0.65 & 0.71 & -1.14 & 1.57 & -0.87 & -0.12 & -0.21 & 1.83 & 1.03 & 1.22 \\
\hline
\end{tabular}

Negative days (pre event) and positive days (post event).

Source: Authors' computations 2017

This trend and movement pattern is shown in the chart below (figure 1). Banking, petroleum (downstream) as well as insurance sector are worst affected in the pre-election period as indicated by their 
respective graphs. The trend for the market progressively became positive with similar advantage to banking, petroleum and insurance stocks. This could perhaps confirm the axiom of higher risk with higher returns.

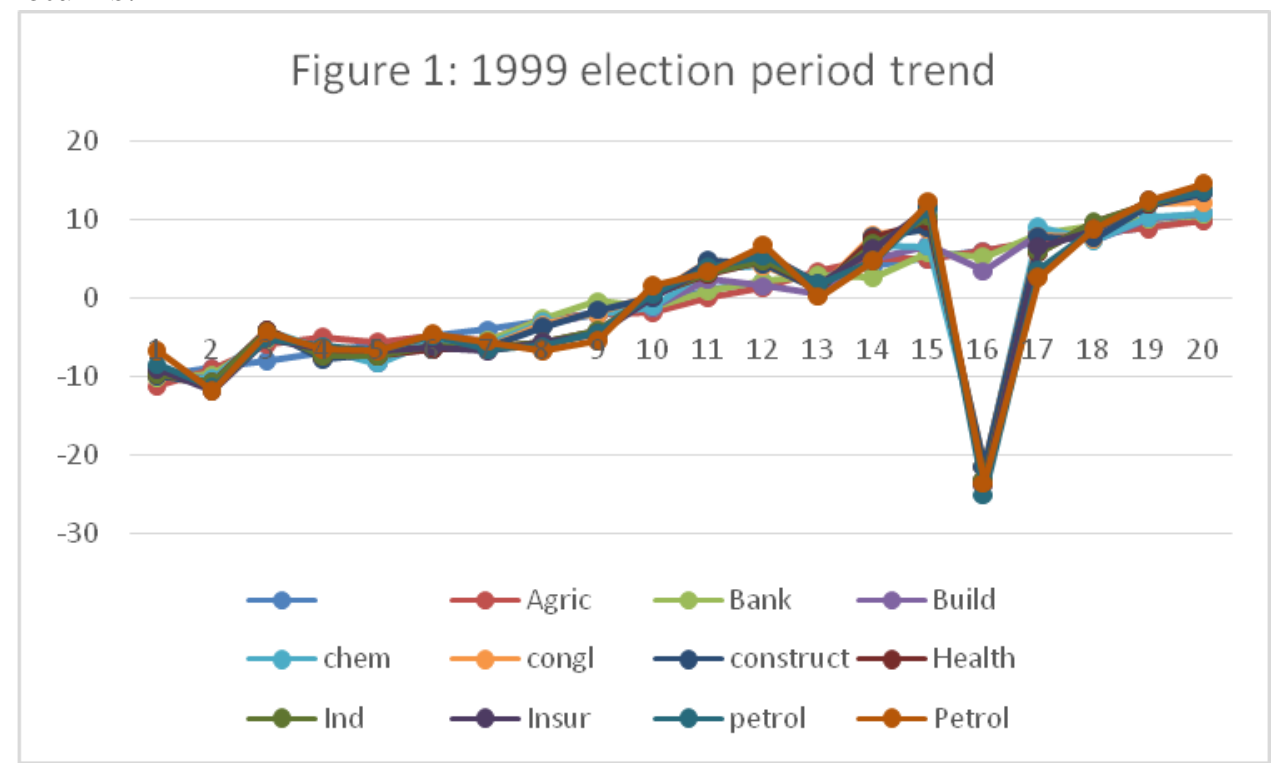

In table 3, the abnormal return trend for 2003 is reported. The general trend in the abnormal returns is that the returns tend to fall consistently from 10 days before elections to 1 day before election. The stock returns tends to improve gradually after the elections. The results indicate that the abnormal returns responded significantly to the period of presidential elections for most of the stocks. Thus, elections might have significantly affected the sock return movement for these forms.

Table (3): Abnormal Returns for the Firms, 2003 (10 days Pre- and post-elections)

\begin{tabular}{|c|c|c|c|c|c|c|c|c|c|c|c|}
\hline Day & agric & Bank & brew & build & chem & Congl & Constr & Health & indust & Insur & Petrol \\
\hline-10 & -0.74 & $\begin{array}{c}- \\
0.59\end{array}$ & 1.51 & $\begin{array}{c}- \\
0.04\end{array}$ & 0.86 & -0.71 & 0.05 & 1.06 & 0.47 & -0.89 & 1.82 \\
\hline-9 & -0.69 & $\begin{array}{c}- \\
0.14\end{array}$ & 0.39 & $\begin{array}{c}- \\
0.99\end{array}$ & -0.05 & -0.21 & 0.04 & -1.19 & -0.99 & -0.90 & -0.42 \\
\hline-8 & -0.64 & 0.23 & 1.33 & 1.20 & 0.01 & 1.00 & -1.41 & -0.77 & 1.04 & 0.30 & 0.82 \\
\hline-7 & 0.24 & 0.00 & $\overline{0.07}$ & $0 . \overline{96}$ & -0.35 & -0.22 & 0.02 & -0.52 & 0.15 & 0.99 & -0.37 \\
\hline-6 & 0.24 & 0.53 & 1.02 & 1.14 & -0.04 & -0.16 & -0.33 & -0.06 & 0.62 & 0.86 & -0.04 \\
\hline-5 & 0.86 & $\begin{array}{c}- \\
0.05\end{array}$ & 1.44 & $2 . \overline{29}$ & -1.34 & -0.58 & -2.74 & -0.56 & -1.06 & -0.55 & 0.16 \\
\hline-4 & 0.24 & 0.29 & 0.96 & 0.84 & 0.65 & 0.51 & -0.11 & -0.94 & -1.41 & -0.84 & 1.01 \\
\hline-3 & 0.23 & 0.83 & $4 . \overline{07}$ & 2.54 & 1.49 & -0.89 & -3.10 & 0.47 & -0.45 & 1.11 & -0.56 \\
\hline-2 & 0.23 & $\overline{0 .} \overline{43}$ & $\begin{array}{c}- \\
1.97\end{array}$ & $\overline{0.07}$ & -1.63 & -1.76 & -2.66 & -0.64 & 0.03 & -0.75 & -0.99 \\
\hline-1 & 0.17 & 0.09 & $1 . \overline{22}$ & 1.78 & -0.33 & 1.16 & -0.05 & 0.60 & 0.79 & 0.98 & 1.04 \\
\hline+1 & 0.23 & 1.68 & 0.17 & 3.47 & -1.97 & 2.03 & 0.06 & 1.19 & -0.25 & 0.18 & -0.56 \\
\hline+2 & 0.23 & 0.16 & 2.03 & 0.28 & -0.01 & -0.15 & -0.30 & 1.03 & -0.53 & -0.30 & 1.36 \\
\hline+3 & 0.23 & 1.04 & 0.07 & 1.59 & -0.32 & 1.74 & -0.05 & -1.41 & -0.05 & 0.89 & -1.61 \\
\hline
\end{tabular}




\begin{tabular}{|c|c|c|c|c|c|c|c|c|c|c|}
\hline 0.23 & 0.40 & 2.41 & 0.39 & 0.06 & 0.19 & -0.06 & 0.56 & -0.91 & 1.12 & -0.05 \\
\hline 0.23 & 0.49 & $\begin{array}{c}- \\
0.62\end{array}$ & 0.10 & 0.25 & -1.22 & 2.63 & 0.55 & 1.47 & 0.06 & 0.99 \\
\hline 0.22 & 0.44 & $\begin{array}{c}- \\
1.20\end{array}$ & 2.10 & 0.13 & -1.29 & -0.07 & 0.03 & 0.20 & -0.45 & 1.55 \\
\hline 0.22 & 0.63 & 0.01 & $\begin{array}{c}- \\
1.57\end{array}$ & 0.32 & -1.13 & 1.73 & 1.74 & -0.61 & 0.60 & -1.00 \\
\hline-1.82 & 0.46 & $\begin{array}{c}- \\
0.09\end{array}$ & 0.67 & 0.57 & 0.91 & -0.20 & 1.72 & -0.27 & 0.33 & -0.11 \\
\hline-1.79 & 0.64 & 0.17 & 1.57 & 1.19 & 1.44 & 2.72 & -2.01 & 0.59 & 2.18 & 0.06 \\
\hline 0.22 & 0.54 & 0.59 & $\begin{array}{c}- \\
0.94\end{array}$ & 1.30 & -0.72 & -0.10 & -0.17 & 1.51 & 0.85 & 1.01 \\
\hline
\end{tabular}

Negative days (pre event) and positive days (post event).

Source: Author's computations 2017

The trend and movement pattern shown in the chart below (figure 2), clearly reveal that Banking, petroleum (downstream) as well as insurance sector are also worst affected in the pre-election period as indicated by these graphs. Though the dispersion was not as that of 1999 perhaps due to improved confidence on the nation's electoral system by investors.

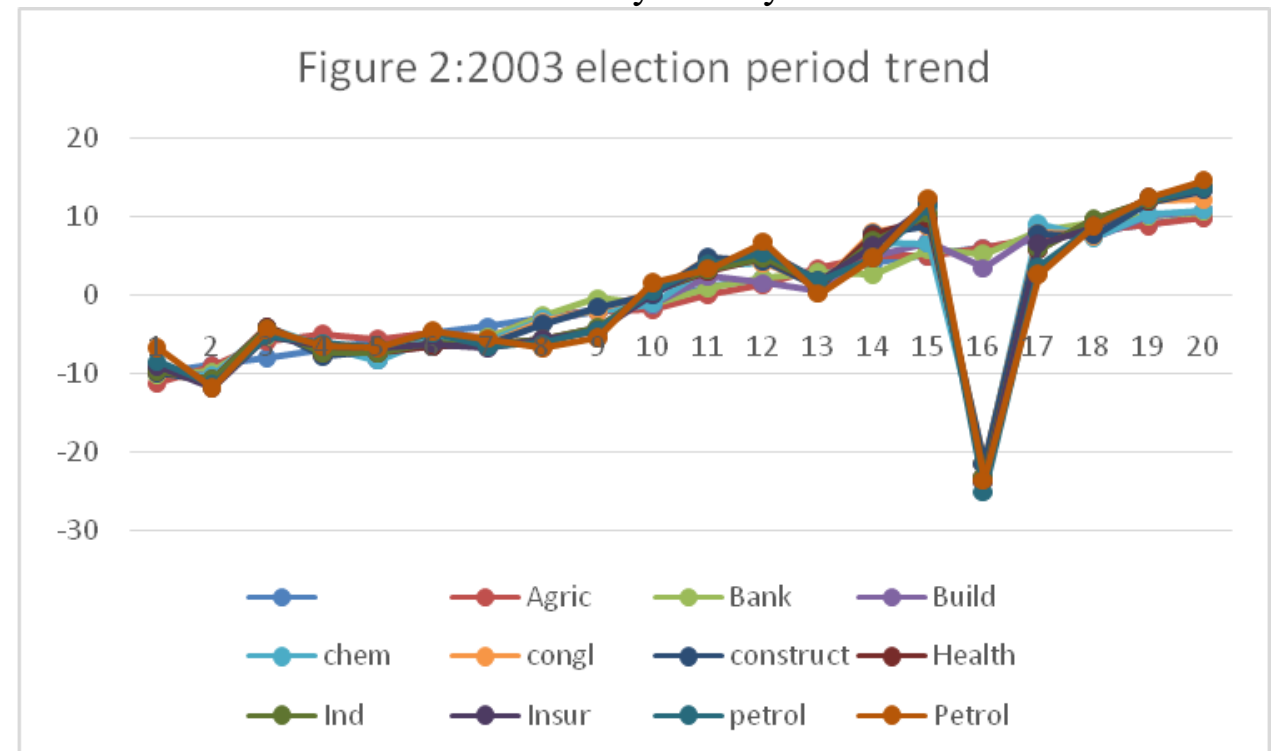

In the abnormal returns table for 2007 as shown in table (vi) below,though the patterns are not quite clear, there is suggestion that the returns fell slightly just before Election Days for most of the categories. There is also an indication of stock returns moving along with election news.

Table (iv): Abnormal Returns for the Firms, 2007 (10 days Pre- and post-elections)

\begin{tabular}{ccccccccccc}
\hline Day & Agric & Bank & Build & chem & congl & construct & Health & Ind & Insur & petrol \\
\cline { 2 - 10 }-10 & -1.21 & 1.06 & 0.31 & -0.11 & 0.09 & 0.02 & 0.09 & -0.02 & 0.69 & 0.55 \\
-9 & -0.04 & -0.72 & -0.66 & 0.14 & -0.69 & -0.03 & 0.20 & 0.05 & -1.08 & 0.42 \\
-8 & 2.06 & 0.68 & 0.37 & 0.63 & 0.15 & 0.03 & -0.04 & -0.21 & -0.83 & -0.04 \\
-7 & 1.99 & -1.37 & -0.22 & 0.20 & -1.28 & -0.05 & 0.23 & 0.06 & 0.99 & 0.25 \\
-6 & 0.34 & -2.29 & -0.42 & -0.07 & 1.27 & 0.00 & -0.30 & 0.07 & 0.73 & -0.06 \\
-5 & 0.04 & -0.36 & -0.13 & 0.05 & -1.05 & -0.02 & -0.08 & 0.33 & -0.05 & 1.44 \\
-4 & -1.49 & 0.10 & -0.64 & 0.10 & -0.44 & -0.01 & 0.05 & 0.04 & -0.48 & 0.16 \\
-3 & 0.30 & -0.02 & -0.56 & 0.19 & -0.39 & -0.19 & -2.14 & 0.10 & 0.10 & -0.62 \\
-2 & -0.02 & 1.56 & -1.71 & 0.17 & 0.02 & 0.44 & -2.71 & 0.06 & -0.40 & 0.10 \\
-1 & -0.80 & 0.50 & 0.03 & 0.18 & 1.30 & -0.16 & 0.33 & 0.06 & -0.32 & 0.35 \\
\hline
\end{tabular}




\begin{tabular}{ccccccccccc}
\hline+1 & -0.92 & 0.86 & 1.43 & 1.41 & 0.96 & 0.01 & -1.81 & 0.16 & 0.73 & 0.07 \\
+2 & -0.68 & 0.78 & -0.59 & 2.67 & -0.08 & 0.22 & 0.41 & -0.06 & 0.99 & -0.27 \\
+3 & 0.34 & -0.57 & -2.29 & 0.79 & -0.28 & -0.07 & 0.21 & 0.08 & 0.54 & 0.01 \\
+4 & 0.84 & -2.30 & 2.43 & 1.76 & 1.31 & -0.16 & -0.29 & -0.67 & -0.70 & -1.51 \\
+5 & -0.03 & 0.77 & 0.96 & -0.17 & 2.21 & 0.20 & 0.83 & 0.49 & 1.35 & -0.32 \\
+6 & -0.05 & -0.70 & -1.82 & - & 0.19 & -0.02 & -1.81 & 0.04 & -0.56 & -1.37 \\
+7 & 0.11 & 1.01 & 0.07 & 0.77 & -1.11 & 0.00 & -2.05 & 0.03 & 0.62 & -2.86 \\
+8 & -0.04 & 1.28 & -1.87 & -0.12 & 0.35 & 0.03 & 1.90 & 0.05 & -0.94 & 0.25 \\
+9 & -0.15 & 1.13 & 0.26 & 0.01 & 1.68 & -0.03 & 0.01 & 0.05 & 0.38 & -0.04 \\
+10 & -0.26 & 0.72 & 0.33 & -0.08 & 1.39 & 1.25 & 0.25 & 0.03 & -0.19 & 0.07 \\
\hline
\end{tabular}

Negative days (pre event) and positive days (post event). Source: Author's computations 2017

The trend and movement pattern shown in the chart below (figure 3) maintained a steady trajectory from negative (at the pre-) to a very weak positive with exception of petroleum (downstream) and chemical stocks nosediving into high negative returns at the post-election days. This can be seen in these graphs.

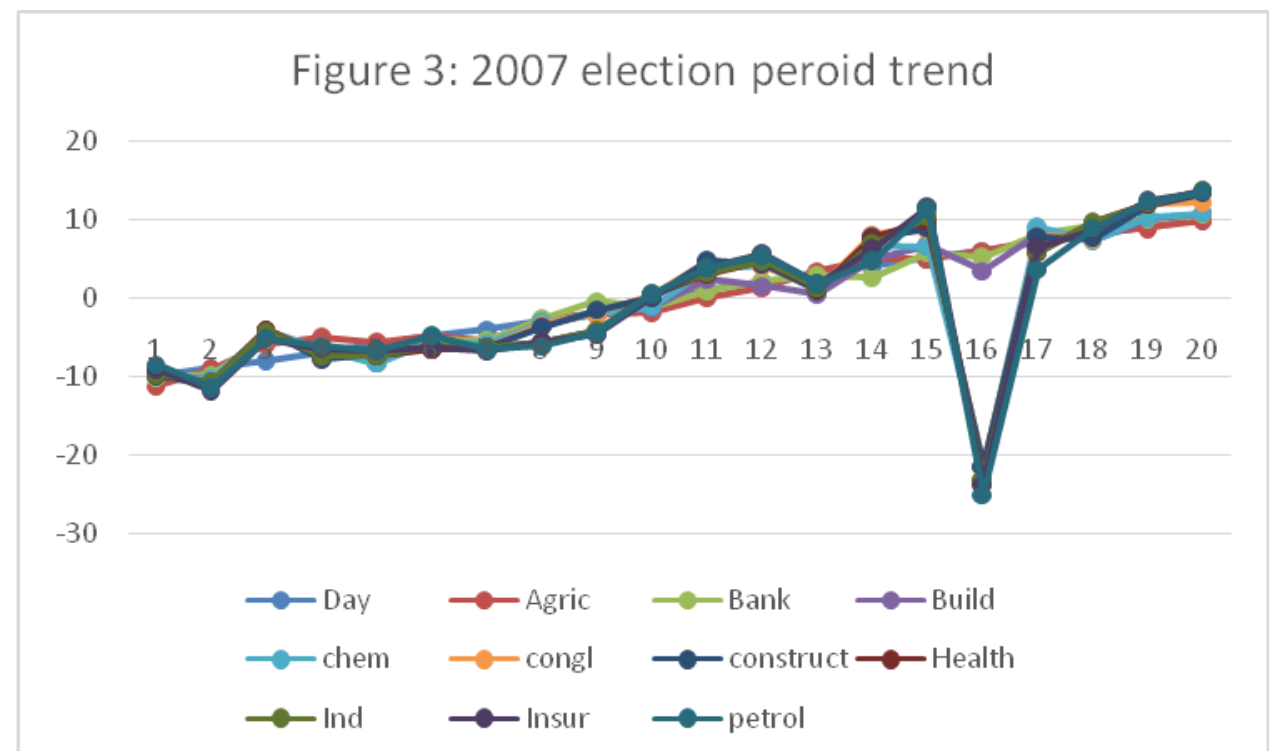

The abnormal returns table for 2011 period is as shown in table (v) below. There indicates that stock prices were negative mostly before elections and improved after the elections. This could be market uncertainty powered by lack of investors' confidence on the different portfolios.

Table (4): Abnormal Returns for the Firms, 2011 (10 days Pre- and post-elections)

\begin{tabular}{ccccccccccc}
\hline Day & Agric & Bank & build & Chem & congl & Construct & Health & Ind & insur & petrol \\
\cline { 2 - 11 }-10 & -1.71 & 1.49 & 0.44 & -0.16 & 0.13 & 0.03 & 0.13 & -0.03 & 0.97 & 0.78 \\
-9 & -0.06 & -1.02 & -0.93 & 0.20 & -0.97 & -0.04 & 0.28 & 0.07 & -1.52 & 0.59 \\
-8 & 2.90 & 0.96 & 0.52 & 0.89 & 0.21 & 0.04 & -0.06 & -0.30 & -1.17 & -0.06 \\
-7 & 2.81 & -1.93 & -0.31 & 0.28 & -1.80 & -0.07 & 0.32 & 0.08 & 1.40 & 0.35 \\
-6 & 0.48 & -3.23 & -0.59 & -0.10 & 1.79 & 0.00 & -0.42 & 0.10 & 1.03 & -0.08 \\
-5 & 0.06 & -0.51 & -0.18 & 0.07 & -1.48 & -0.03 & -0.11 & 0.47 & -0.07 & 2.03 \\
-4 & -2.10 & 0.14 & -0.90 & 0.14 & -0.62 & -0.01 & 0.07 & 0.06 & -0.68 & 0.23 \\
-3 & 0.42 & -0.03 & -0.79 & 0.27 & -0.55 & -0.27 & -3.02 & 0.14 & 0.14 & -0.87 \\
-2 & -0.03 & 2.20 & -2.41 & 0.24 & 0.03 & 0.62 & -3.82 & 0.08 & -0.56 & 0.14 \\
-1 & -1.13 & 0.71 & 0.04 & 0.25 & 1.83 & -0.23 & 0.47 & 0.08 & -0.45 & 0.49 \\
1 & -1.30 & 1.21 & 2.02 & 1.99 & 1.35 & 0.01 & -2.55 & 0.23 & 1.03 & 0.10
\end{tabular}




\begin{tabular}{|c|c|c|c|c|c|c|c|c|c|c|}
\hline 2 & -0.96 & 1.10 & -0.83 & 3.76 & -0.11 & 0.31 & 0.58 & -0.08 & 1.40 & -0.38 \\
\hline 3 & 0.48 & -0.80 & -3.23 & 1.11 & -0.39 & -0.10 & 0.30 & 0.11 & 0.76 & 0.01 \\
\hline 4 & 1.18 & -3.24 & 3.43 & 2.48 & 1.85 & -0.23 & -0.41 & -0.94 & -0.99 & -2.13 \\
\hline 5 & -0.04 & 1.09 & 1.35 & -0.24 & 3.12 & 0.28 & 1.17 & 0.69 & 1.90 & -0.45 \\
\hline 6 & -0.07 & -0.99 & -2.57 & 35.28 & 0.27 & -0.03 & -2.55 & 0.06 & -0.79 & -1.93 \\
\hline 7 & 0.16 & 1.42 & 0.10 & 1.09 & -1.57 & 0.00 & -2.89 & 0.04 & 0.87 & -4.03 \\
\hline 8 & -0.06 & 1.80 & -2.64 & -0.17 & 0.49 & 0.04 & 2.68 & 0.07 & -1.33 & 0.35 \\
\hline 9 & -0.21 & 1.59 & 0.37 & 0.01 & 2.37 & -0.04 & 0.01 & 0.07 & 0.54 & -0.06 \\
\hline 10 & -0.37 & 1.02 & 0.47 & -0.11 & 1.96 & 1.76 & 0.35 & 0.04 & -0.27 & 0.10 \\
\hline
\end{tabular}

Negative days (pre event) and positive days (post event). Source: Author's computations 2016

The trend and movement pattern shown in the chart below (figure 4) maintained similar trajectory of the 2007 election. From negative (at the pre-) to a very weak positive with exception of banking, petroleum (downstream) and chemical stocks nosediving into very high negative returns at the post-election days. This can be seen in these graphs.

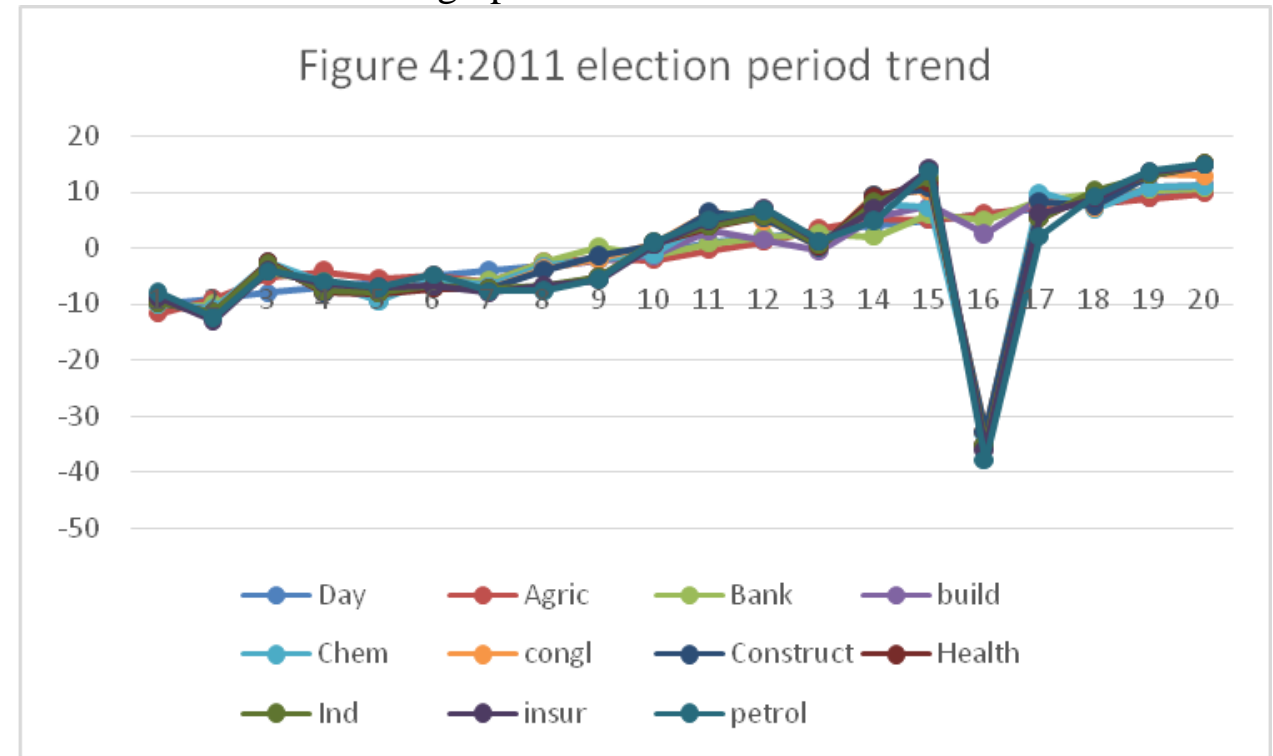

Essentially, the overall outcome of the trend of abnormal return during this 10-day period around elections generally indicates that most of the stocks actually responded in an abnormal pattern to the presidential elections in Nigeria. The path of their movements was effectively altered by either the news of the coming elections or the general outcome of the elections.

\section{Empirical Analysis of the Cumulative Abnormal Returns (CAR)}

Here we conducted the empirical test on the cumulative abnormal returns for the event window (of six days) in order to observe whether a significant difference exists in its pattern over the event (presidential elections) periods. In table (6), the results of cumulative abnormal return along with the computed $t$ statistics for the event window in all the election years are reported. It is based on the outcome of the results of CAR that decision on the event study is determined.

For the 2011 elections, only the CAR for banking, breweries and petroleum sectors were significant, indicating a significant abnormal return level during the 2011 presidential election period. For banking and petroleum sectors, positive CARs were revealed. This implies that returns on their stocks actually rose after the 2011 presidential election. Hence it is a better time to sell those portfolios i.e. after the election. For the breweries, the results show that a fall in return on these stocks was experienced after the election period in 2011. Therefore, investors could buy these stocks that experience loss in value at a postelection window. For the 2007 election, only the chemicals/banking and petroleum sectors experienced significant changes in their returns, judging from the fact that only their CARs are significant at the 5 
percent level. For 2003, the banking sector, conglomerates and petroleum sectors had significant CARs. The year with the highest number of industrial growth with significant CARs is 1999.These includes Banking, Building and Conglomerate. Also on the list are Breweries and Petroleum sub-sector of the nation's economy.This is not unconnected with the import dependent and foreign portfolios status of the nation economy instead of direct investment. The direction of market returns and owners connectivity are inextricably linked.

Table (6): Cumulative Abnormal Returns for Presidential Election Periods, 1999-2011

\begin{tabular}{|c|c|c|c|c|}
\hline INDUSTRY & 2011 & 2007 & 2003 & 1999 \\
\hline \multirow{2}{*}{ Agriculture } & 0.02 & 0.04 & -0.07 & 0.11 \\
& $(0.86)$ & $(1.17)$ & $(-1.09)$ & $(1.01)$ \\
\hline \multirow{2}{*}{ Banking } & $0.11^{*} *$ & $0.26^{*}$ & $0.09 *$ & $0.13^{*}$ \\
& $(3.11)$ & $(2.92)$ & $(2.31)$ & $(2.31)$ \\
\hline \multirow{2}{*}{ Breweries } & $-0.23^{*} *$ & 0.11 & -0.11 & $0.52^{*}$ \\
& $(-4.18)$ & $(1.13)$ & $(-1.75)$ & $(2.75)$ \\
\hline \multirow{2}{*}{ Building } & -0.83 & -0.21 & 0.16 & $-0.21^{*}$ \\
& $(-1.81)$ & $(-1.11)$ & $(1.69)$ & $(3.02)$ \\
\hline \multirow{2}{*}{ chemicals } & 0.28 & 0.28 & 0.02 & 0.02 \\
& $(0.71)$ & $(0.71)$ & $(0.43)$ & $(0.64)$ \\
\hline \multirow{2}{*}{ conglomerates } & 0.07 & 0.03 & $0.04 *$ & $0.12 *$ \\
& $(0.21)$ & $(0.73)$ & $(2.09)$ & $(3.34)$ \\
\hline \multirow{2}{*}{ construction } & -0.33 & -0.33 & -0.23 & 0.17 \\
& $(-1.15)$ & $(-1.15)$ & $(-0.92)$ & $(0.22)$ \\
\hline \multirow{2}{*}{ Healthcare } & 0.04 & 0.19 & 0.05 & 0.02 \\
& $(0.71)$ & $(1.12)$ & $(0.22)$ & $(0.22)$ \\
\hline \multirow{2}{*}{ Industrial } & 0.08 & 0.04 & 0.05 & 0.12 \\
& $(1.02)$ & $(0.08)$ & $(0.41)$ & $(0.77)$ \\
\hline \multirow{2}{*}{ Insurance } & -0.17 & 0.24 & 0.31 & 0.13 \\
& $(-1.57)$ & $(0.57)$ & $(1.61)$ & $(1.09)$ \\
\hline \multirow{2}{*}{ Petroleum } & $0.47 *$ & $0.81^{*} *$ & $0.24 *$ & $0.19 *$ \\
& $(2.78)$ & $(3.12)$ & $(2.55)$ & $(2.92)$ \\
\hline \multirow{2}{*}{ Note: t-values }
\end{tabular}

Note: $t$-values are in parenthesis

Source: Authors' computations 2017

Below is a chart to further show the CAR for the various industries and their relationship with various presidential elections in Nigeria (figure 5) 


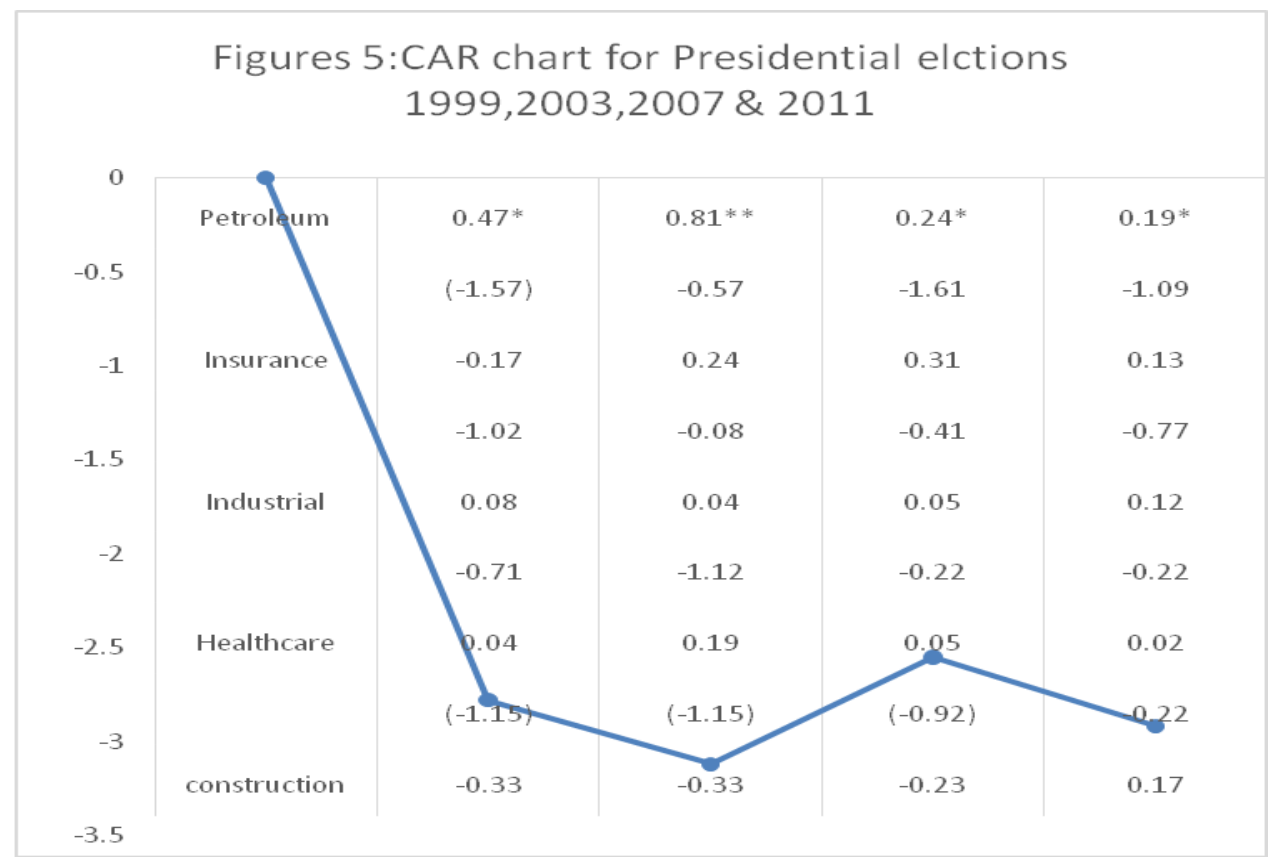

\section{Conclusion, Policy Implication and Recommendations}

The relationship between electoral events and sectoral stock returns in the Nigerian appears significant as revealed by this study. The stocks of banking, Petroleum, chemical and insurance sectors revealed a disproportional movement. Perhaps, due to weak corporate governance practices in Nigeria, owners' connectivity with the various governments in power is at play. This manifests as their stock returns tend to reduce generally during election periods definitely due to stripping of their stake to fund the political parties of their interest. However, these negative effects have dropped over subsequent elections in Nigeria, this perchance may not be unconnected with the marginal strengthening of the political institutions as well as increase voters education.

Politics has always served as a pivot for societal interactions since the evolution of modern systems. It is becoming increasingly clear that political affairs, financial market performance and macroeconomic indicators are indistinguishably linked among national economic indicators (Eboigbe, 2016).

A critical look by way of fact-checking the Nigerian operational environment of business reveal the following key actors: From the Banking sector, Tajudeen Afolabi Adeola the former vice presidential candidate of Action Congress Party of Nigeria was in the saddle for the various elections in Guaranty Trust Bank plc. Jim Ovia and the current Governor of Central Bank of Nigeria- Godwin Emefeile were at the helm of affairs at Zenith Bank Plc (ZBN); Anthony Onyemaechi Elumelu of United Bank of Africa Plc (UBA) and his brother Ndudi Elumelu (former member of the Federal House of Representatives). Also on the list of politically connected business moguls are Alex Otti, Femi Otedola, Jimoh Ibrahim etc. These politically exposed persons have controlling interest in oil and gas sector, insurance, banking, hotels and hospitality business sectors as well as overt political interest.

For instance, it is known that with the sensitivity of the financial markets especially in developing countries, making use of monetary policies alone is quite ineffective in stimulating output at any given particular time without the addition of other political and behavioural tools. This study has justify why notable global investment decision theories and rules are not sufficient for the present $21^{\text {st }}$ century competitive business forecast. Therefore political, financial and economic indicators need to be integrate into local and international investment theories.

Consequently, the findings that some industries are adversely affected by election outcomes justify high job losses from such sectors, thereby putting the various stakeholders on notice so as to review political parties funding policies. This is because of our estimation that the connectivity of such industry players is 
being rewarded by such industry-specific losses and gains within the event windows.

In the light of these, we recommend the entrenchment of independence for institutions with constitutional and operational mandate to regulate macroeconomic factors that could affect aggregate economic activities. This will help by depoliticizing policy framework through political manoeuvrings of the economy by creating industry-specific expansionary and contractionary policies without the economic fundamentals. These will help to strengthen public institutions by discouraging the influence of politically-exposed and connected actors on the national indices.

\section{References}

Agrawal, A.,\&Knoeber, C. (2001). Do some outside directors play a political role? Journal of Law and Economics, 44, 179-198.

Aggarwal, R. K., Meschke, F.,\& Wang, T. Y. (2008). Corporate political contributions: investment or agency, working paper.

Bertrand, M., Kramarz, F, Schoar, A.,\&Thesmar, D. (2007). Politicians, firms and the political business cycle: Evidence from France, working paper, university of Chicago.

Bertrand, M., Kramarz, F., Schoar, A.,\&Thesmar, D. (2008). Politicians, firms and the political business cycle: evidence from France, working paper, university of Chicago.

Blomberg, S.B.,\& Hess, G.D. (2003). Is the political business cycle for real? Journal of Public Economics, 8, 1091-1121

Boubakri, N., Cosset, J.C.,\&Saffar, W. (2008). Political connections and newly privatized firms, Journal of Corporate Finance, 14, 654-673.

Bunkanwanicha, P.,\&Wiwattanakantang, Y. (2009). Big business owners in politics. Review of Financial Studies, 22(6), 2133-2168.

Campbell, C. J.,\&Wasley, C.E. (1997). Measuring security price performance using daily NASDAQ returns, Journal of Financial Economics, 33(1), 73-92. Cohen, L., Frazzini, A.,\& Malloy, C. (2008). The small world of investing: board connections and mutual funds returns. Journal of Political Economy 116(5), 951-79.

Claessens, S., Feijen, E.,\&Laeven, L. (2008). Political connections and preferential access to finance: the role of campaign contributions, Journal of Financial Economics, 88,554-580.

Do, Q.A., Lee, Y., Nguyen, B. D.,\& Nguyen, K. (2012). Out of sight, out of mind: the value of political connections in social networks. Unpublished working paper, https://www.aeaweb.org

Eboigbe, S.U. (2016).Political Events, Capital Markets and Economic Performances of selected Countries, PhD Thesis, University of Benin, Nigeria

Faccio, M. (2006). Politically connected firms, American Economic Review, 96(1), 369-386

Faccio, M., Masulis, R.W.,\& McConnell, J.J (2006). Political connections and corporate bailouts, Journal of Finance, 61, 2597-2635.

Faccio, M.,\& Parsley, D (2007). Sudden death: Taking stock of political connections, Journal of Financial and Quantitative Analysis, 33, 683-718.

Fisman, R. (2001). Estimating the value of political connections. American Economic Review, 91(4), 1095-1102.

Fisman, D., Fisman, R., Galef, J.,\&Khurana, R. (2006). Estimating the value of connections to vicepresident Cheney, B.E. Journal of Economic Analysis \& Policy 13(3), 203- 238.

Fracassi, C. (2009). Corporate finance policies and social networks. Unpublished paper.

Goldman, E., Rocholl, J.,\& So, J. (2008). Political connections and the allocation of procurement contracts, unpublished working papers. Indiana University, the European School of Management and Technology, and the University of Korea, retrieve 15th October 2015.

Goldman, E., Rocholl, J.,\& So, J. (2009). Do politically connected boards affect firm value? Review of Financial Studies 22, 2331-2360.

Goodell, J. W.,\&Vahamaa, S. (2013). U.S. presidential elections and implied volatility: The role of political uncertainty. Journal of Banking \& Finance, 37, 1108-1117.

Greenwood, R.,\&Thesmar, D. (2011). Stock price fragility. Journal of Financial Economics 102 (3), 
471-490

Guner, A. B., Malmendier, U.,\& Tate, G. (2008). Financial expertise of directors, Journal of Financial Economics, 88, 323-354

Johnson, S.,\& Mitton, T. (2003). Cronyism and capital controls: Evidence from Malaysia,

Journal of Financial Economics, 67(2), 351-382.

Jayachandran, S. (2006). The Jeffords effect, Journal of Law and Economics, 49, 397 - 425

Khwaja, A. I.,\&Mian, A. (2005). Do lenders favour politically connected firms? Rent provision in an emerging financial market, Quarterly Journal of Economics, 120, 1371- 1411.

Knight, B. G. (2007). Are policy platforms capitalized into equity prices? Evidence from the Bush/Gore 2000 presidential election. Journal of Public Economics, 91(1-2), 389-

Kramarz, F.,\&Thesmar, D. (2007). Politicians, firms and the political business cycle: Evidence from France. Journal of Finance 62 (2), 597-628

Kroszner, R.,\& Strahan, P. (2001). Bankers on boards: Monitoring, conflicts of interest, and lender liability, Journal of Financial Economics, 62, 415-452.

Mackinlay, A.C. (1997).Event studies in economics and finance, Journal of Economic $\quad$ Literature 35 , 13-39.

Nguyen, B. D. (2012). Does the rolodex matter? Corporate elite's small world and the effectiveness of boards of directors. Management Science 58 (2), 236-252.

Roberts, B. E. (1990). A dead senator tells no lies: Seniority and the distribution of federal benefits, American Journal of Political Science, 34(1), 31-58.

Santa-Clara, P.,\&Valkanov, R. (2003). The presidential puzzle: Political cycles and the stock market. Journal of Finance, 58, 1841-1872.

Sy, O.,\& Al Zaman, A. (2011). Resolving the presidential puzzle, Financial Management40(2), 331-355. 
